\title{
PENERAPAN MODEL COOPERATIVE LEARNING TIPE STAD UNTUK MENINGKATKAN AKTIVITAS DAN HASIL BELAJAR PKN SISWA KELAS VI SD NEGERI 016 KUNTO DARUSSALAM SEMESTER 1 TAHUN PELAJARAN 2017/ 2018
}

\author{
SUMARNO \\ Guru SD N 016 Kunto Darussalam Rokan Hulu
}

\begin{abstract}
ABSTRAK
Berdasarkan observasi yang dilakukan di kelas VI SDN 016 Kunto Darussalamdiketahui aktivitas dan hasil belajar siswa masih rendah khususnya pada pelajaran PKn. Penelitian ini bertujuan untuk meningkatkan aktivitas dan hasil belajar siswa kelas VI DN 016 Kunto Darussalam rmelalui penerapan model CooperativeLearningtipe Student Teams Achievement Division (STAD). Penelitian ini menggunakan penelitian tindakan kelas yang memiliki tahapan perencanaan, pelaksanaan, observasi, dan refleksi, dilaksanakan dalam dua siklus, setiap siklus dilakukan dalam dua pertemuan. Subjek penelitian dalam penelitian ini adalah siswa kelas VI DN 016 Kunto Darussalam dengan jumlah siswa sebanyak 16 siswa terdiri dari siswa laki-laki dan perempuan siswa. Data yang diperlukan diperoleh melalui observasi, dokumentasu dan tes menggunakan soal-soal tes. Validitas data dilakukan dengan teknik triangulasi. Data yang terkumpul dianalisis dengan teknik analisis kualitatif dan kuantitatif. Hasil penelitian menunjukkan bahwa pembelajaran PKn dengan menggunakan model Cooperative Learning tipe Student Teams Achievement Division (STAD), dapat meningkatkan aktivitas dan hasil belajar siswa. Adapun hasil rata-rata tes formatif secara individu adalah sebagai berikut : kondisi awal sebesar 65,50, siklus I adalah 74,56, siklus II adalah 83,00 dengan ketuntasan belajar dari 2 siswa atau 12,50\% menjadi 62,50\%, atau 10 siswa dan 93,75\% atau 15 siswa pada siklus terakhir serta penilaian hasil observasi aktivitas belajar yang juga meningkat di mana pada kondisi awal sebesar 18,75\% atau 3 siswa, siklus I sebesar 62,50\% atau 10 siswa, meningkat menjadi $100 \%$ atau 16 siswa. Kesimpulannya adalah penerapan penerapan model cooperative learning tipe STAD dapat meningkatkan aktivitas dan hasil belajar siswa pada pembelajaran PKn di Kelas VI DN 016 Kunto Darussalam
\end{abstract}

Kata Kunci : $S T A D$, aktivitas, hasil belajar

\section{PENDAHULUAN}

Pendidikan merupakan proses mengubah tingkah laku anak didik agar menj manusia dewasa yang mampu hidup mandiri dan sebagai anggota masyarakat dalam lingkungan alam sekitar dimana individu itu berada. Pendidikan tidak hanya mencakup pengembangan intelektualitas saja, akan tetapi lebih ditekankan pada proses pembinaan kepribadian anak didik secara menyeluruh sehingga anak menjadi lebih dewasa. Sagala (2011:3). Pendidikan dasar merupakan jenjang pendidikan yang harus terlebih dahulu diselesaikan oleh siswa atau pelajar sebelum mencapai pendidikan yang lebih tinggi lagi yaitu sekolah lanjutan hingga perguruan tinggi itu semua dilaksanakan oleh generasi muda sebagai suatu kewajiban yang harus dilaksanakan sebagai warga Negara.Pendidikan juga dapat berfungsi sebagai filter adanya pengaruh dari adanya era globalisasi yang sekarang sedang terjadi di seluruh dunia.

Pendidikan Kewarganegaraan (PKn) sebagai salah satu ilmu dasar di sekolah yang mempunyai peranan penting dalam rangka upaya mencetak generasi bangsa yang mempunyai budi pekerti dan kepribadian yang unggul sebagai warga negara Indonesia. PKn juga sebagai sarana untuk mengembangkan kecerdasan, kepribadian, watak, sopan santun, sikap, toleransi, saling menghargai dan rasa keperdulian dengan sesama.sering kali PKn dianggap sebagai salah satu mata pelajaran yang disepelekan dianggap kurang penting dan tidak begitu diminati oleh para pelajar atau siswa. Hal ini juga dikarenakan proses pembelajaran disekolah-sekolah pada palajaran PKn juga masih sangat konfensional yaitu guru masih merupakan pusat pembelajaran guru masih menggunakan metode ceramah saat pembelajaran, hal itu menjadikan siswa juga seringkali merasa bosan dan jenuh pada saat pelajaran berlangsung, akibatnya materi yang diajarkan oleh guru tidak maksimal diserap oleh siswa dan materi kurang dipahami oleh siswa.

Pembelajaran yang efektif dan efisien adalah harapan setiap guru. Semakin ke depan materi pembelajaran semakin banyak dengan waktu yang tidak bertambah. Seorang guru hendaklah menerapkan model pembelajaran yang baik untuk proses pembelajaran yang akan 
dilaksanakan. Oleh karena itu, bila model pembelajaran atau metode yang dipakai tidak cocok akan menimbulkan masalah dalam pembelajaran. Bila masalah ini dibiarkan berlarut larut maka akan menimbulkan penurunan kualitas pembelajaran. Oleh sebab itu, peneliti mencoba mengidentifikasi masalah yang terjadi dalam pembelajaran yang dilakukan.

Mata pelajaran PKn merupakan salah satu mata pelajaran yang bisa menerapkan hal ini. PKn adalah salah satu mata pelajaran yang mempelajari tentang nilai-nilai dan norma pancasila maupun moral, yang menuntut setiap pendidik untuk kreaktif dalam menyajikan materi, guna memotivasi siswa mendapatkan hasil belajar yang baik. Sebab berhasil tidaknya pendidik dalam suatu kegiatan belajar mengajar dapat dilihat dari motivasi belajar seorang peserta didik. motivasi belajar merupakan salah satu perilaku secara keseluruhan bukan hanya salah satu aspek potensi kemanusiaan saja pada peserta didik melainkan mencakup seluruh aspek. (Daryono, dkk. 2008:1) Aktivitas merupakan akibat dari interaksi seseorang dengan situasi tertentu yang dihadapinya. Karena itulah terdapat perbedaan dalam kekuatan aktivitas yang ditunjukan oleh seseorang dalam menghadapi situasi tertentu dibandingkan dengan orang-orang menghadapi situasi yang sama. Bahkan seseorang akan menunjukan dorongan tertentu dalam menghadapi situasi yang berbeda dan dalam waktu yang berlainan pula, berarti apabila berbicara mengenai aktivitas salah satu 3 hal yang amat penting untuk diperhatikan ialah bahwa tingkat aktivitas berbeda antara seorang dengan orang lain dan dalam diri seseorang pada waktu yang berlainan. Meningkatkan aktivitas belajar siswa dapat dilakukan dengan menerapkan proses belajar mengajar yang benar, sebab proses belajar mengajar merupakan upaya pendidikan paling penting dalam proses pembelajaran. Sehingga dapat diketahui bahwa proses belajar mengajar adalah inti kegiatan yang menjadi tolak ukur peningkatan mutu pendidikan, untuk mencapai hasil belajar. Mencapai hasil belajar yang maksimal untuk menciptakan pendidikan yang bermutu tentunya dibutuhkan komponen pendidikan yang berkualitas dan memadai.
Salah satunya adalah pendidik yang profesional. Saat ini banyak guru yang kurang profesional dalam melakukan tugasnya.

Hasil penelitian awal yang telah peneliti lakukan masih terdapat perbedaan antara harapan dengan kenyataan yang terjadi dalam pembelajaran Ilmu Pengetahuan Sosial materi menjelaskan perbedaan jenis kelamin, agama, dan suku bangsa. Harapan yang demikian itu nyata belum bisa dipenuhi oleh seluruh siswa kelas VI SDN 016 Kunto Darussalam

Hal ini dibuktikan dengan hanya empat siswa yang mencapai nilai standar KKM (76) ke atas hanya 2 siswa atau $12,50 \%$, dengan aktivitas belajar siswa yang hanya mencapai angka $18,75 \%$ atau hanya 3 siswa dari 16 siswa serta perolehan nilai rata-rata hasil belajar secara klasikal sebesar 65,50. Rendahnya hasil belajar dan aktivitas belajar PKn dipengaruhi oleh berbagai faktor. Faktor yang mendukung pelaksanaan pembelajaran pada dasarnya sangat kompleks dan bisa ditinjau dari berbagai aspek. Adapun hal yang paling mendasar dan menentukan terhadap keberhasilan pembelajaran diantaranya sarana dan prasarana yang memadai, situasi dan kondisi yang kondusif, faktor guru, faktor siswa, termasuk pemilihan dan penggunaan model pembelajaran.

Diantara berbagai model pembelajaran, satu diantaranya adalah model cooperative learning tipe STAD, yaitu pembelajaran berkelompok dimana siswa dapat saling membantu dalam proses pembelajaran sehingga siswa yang kurang dapat dibantu oleh teman kelompoknya selain oleh guru sebagai pembimbing. Model ini memberikan kesempatan kepada siswa untuk belajar secara bersama-sama atau gotong royong sehingga makna kebersamaan sangat dominan. Selain itu, model ini dapat mengaktifkan siswa dalam belajar karena siswa didorong untuk mengemukakan pendapat atau menyanggah berbagai masalah yang diajukan oleh rekan sekelompoknya.

\section{Kajian Teori}

KAJIAN PUSTAKA

\section{Model Cooperative Learning}

a. Pengertian Coopertive Learning 
Model Coopertive Learning atau model pembelajaran gotong royong ini didasari oleh falsafah homo homoni socius, yang menekankan manusia adalah makhluk sosial. Ini mengandung arti, kerja sama merupakan kebutuhan sangat penting bagi kelangsungan hidup manusia. Model Coopertive Learning menekankan pada pemberian kesempatan belajar yang lebih luas dan suasana yang kondusif kepada siswa untuk memperoleh dan mengembangkan pengetahuan, sikap, nilai serta keterampilan-keterampilan sosial yang bermanfaat bagi kehidupannya di masyarakat.

Coopertive Learning ini dianggap perlu dalam pendidikan, karena tidak setiap orang bisa dan mampu bekerja sama. Tidak ada seorang pun yang sejak lahir mempunyai kemampuan untuk bekerja sama dengan baik. Kemampuan itu harus dipelajari. Ini termasuk yang disebut dengan social-skill atau kecakapan hidup bermasyarakat. Melalui belajar bekerja sama akan muncul berbagai sikap sosial yang positif, di antaranya saling menghargai dan menghormati, toleransi, tenggang rasa, kemampuan mengendalikan emosi, kesediaan untuk saling berbagi (take and give).

Terdapat beberapa definisi pembelajaran kooperatif atau Cooperative Learning yang dikemukakan oleh beberapa ahli pendidikan sebagai berikut :

1) Davidson dan Korl (Sutardi dkk, 2007: 57), mendefinisikan bahwa "Pembelajaran kooperatif (Coopertive Learning) ialah kegiatan yang berlangsung di lingkungan belajar siswa dalam kelompok kecil yang saling berbagi ide-ide dan bekerja secara kolaboratif untuk memecahkan masalah- masalah yang ada dalam tugas mereka".

2) Karli dan Margaretha (2004: 47) menjelaskan bahwa "Model belajar kooperatif adalah suatu strategi belajar mengajar yang menekankan pada sikap atau perilaku bersama dalam bekerja atau membantu diantara sesama dalam struktur kerjasama yang teratur dalam kelompok yang terdiri atas dua orang atau lebih untuk memecahkan masalah".

3) Sedangkan menurut Sanjaya (2006: 240) "Pembelajaran kooperatif (Coopertive
Learning) merupakan model pembelajaran dengan menggunakan sistem pengelompokan tim kecil, yaitu antara empat sampai enam orang yang mempunyai latar belakang akademis, jenis kelamin, ras, atau suku yang berbeda". Melalui beberapa pendapat di atas dapat ditarik kesimpulan bahwa yang dimaksud dengan model Coopertive Learning adalah cara belajar bersama sama dalam sebuah kelompok heterogen yang terdiri atas dua orang atau lebih yang saling membantu antar satu dengan yang lainnya untuk membahas dan menyelesaikan tugas atau memecahkan masalah.

\section{b. Prinsip Cooperative Learning}

Pembelajaran kooperatif atau Cooperative Learning setidaknya memiliki lima prinsip yaitu:

1) Belajar siswa aktif ( student active learning )

Proses pembelajaran berpusat pada siswa, aktivitas belajar lebih dominan oleh siswa, pengetahuan yang dibangun dan ditemukan adalah belajar bersama-sama dengan anggota kelompok sampai masingmasing siswa memahami materi pembelajaran dan diakhiri dengan membuat laporan kelompok dan individual.

\section{2) Belajar bekerjasama (Cooperative Learning)}

Proses pembelajaran dilalui dengan bekerjasama dalam kelompok untuk membangun pengetahuan yang tengah dipelajari. Prinsip pembelajaran inilah yang melandasi keberhasilan penerapan model Coopertive Learning. Seluruh siswa terlibat secara aktif dalam kelompok untuk melakukan diskusi, memecahkan masalah dan mengujinya secara bersama. Pengetahuan yang diperoleh hasil kerjasama diyakini lebih bernilai permanen.
3) Pembelajaran Parsipatorik (Participatoric learning)

Melaui model pembelajaran ini, siswa belajar dengan melakukan sesuatu atau learning by doing secara bersama-sama untuk menemukan dan membangun pengetahuan yang menjadi tujuan pembelajaran. 4) Mengajar Reaktif (Reactive teaching) 
Motivasi siswa dapat dibangkitkan jika guru mampu menciptakan suasana belajar yang menyenangkan dan menarik serta dapat meyakinkan siswanya akan manfaat pelajaran untuk masa depan mereka.

5) Pembelajaran yang menyenangkan ( Joyfull leraning)

Pembelajaran yang menyenangkan harus dimulai dari sikap dan perilaku guru di luar mapun di dalam kelas.

\section{Cooperative Learning Teknik STAD}

Salah satu model pembelajaran kooperatif adalah model Student Team Achievement Divisions (STAD). STAD adalah salah satu tipe pembelajaran kooperatif yang sederhana. Model pembelajaran Coopertive Learning Tipe STAD adalah model pembelajaran dengan strategi kelompok belajar yang terdiri dari 4 sampai 5 siswa yang heterogen dari kemampuan belajarnya, ada siswa yang kemampuan belajarnya tinggi, sedang maupun rendah.

Dalam kelompok tersebut ada tanggung jawab bersama, jadi setiap anggota aling membantu untuk menutupi kekurangan temannya. Ada proses diskusi, saling bertukar pendapat, menghargai pendapat,pembelajaran teman sebaya. kepemimpinan dalam mengatur pembelajaran di kelompoknya sehingga yang terjalin adalah hubungan positif. Guru menyajikan pelajaran kemudian siswa bekerja dalam tim untuk memastikan bahwa seluruh anggota tim telah menguasai pelajaran tersebut. Akhirnya seluruh siswa diberi kuis tentang materi itu dengan catatan saat kuis mereka tidak boleh saling membantu. Tipe pembelajaran inilah yang akan diterapkan dalam pembelajaran PKn.

Keunggulan dari metode pembelajaran kooperatif teknik STAD adalah adanya kerja sama dalam kelompok dan dalam menentukan keberhasilan kelompok tergantung keberhasilan individu, sehingga setiap anggota kelompok tidak bisa menggantungkan pada anggota yang lain. Pembelajaran kooperatif teknik STAD menekankan pada aktivitas dan interaksi diantara siswa untuk saling memotivasi saling membantu dalam menguasai materi pelajaran guna mencapai prestasi yang maksimal.

Adapun langkah-langkahnya adalah sebagai berikut :

1) Guru memberikan penjelasan

Jelasnya guru menerangkan (ekspositori) materi baru, memberi contoh cara mengerjakan soal baru, meragakan keterampilan baru dsb.

2) Murid belajar dalam tim atau kelompok

Dalam tim atau kelompok itu murid-murid secara bersama memperdalam atau memperluas materi pelajaran, atau "menderes" (mengulang menghapalkan) materi pelajaran), atau berlatih bersamasama (bekerja sama) mengerjakan soalsoal ("quiz latihan," LKS, dsb.). Jadi, untuk tahap kedua STAD itu (kerja tim) guru harus menyediakan tugas yang harus dikerjakan oleh semua kelompok. Misalnya murid bersama-sama berlatih menghitung luas segi tiga dengan ukuran yang berbeda-beda yang sudah disediakan guru.

3) Tes akhir sesi

Pada akhir "sesi," bisa akhir satu pertemuan, dua pertemuan, atau tiga pertemuan, tergantung pada isi pokok bahasan atau materi pelajaran, dan perkiraan siswa dapat menangkap atau menguasai pelajaran, diadakanlah tes individual, dengan "quiz tes," misalnya. Dalam tes ini tentu tidak ada lagi kerja sama.

4) Penilaian dan pemberian penghargaan.

Tes akhir sesi dikoreksi (dinilai) guru untuk nantinya diberitahukan kepada seluruh siswa. Ada pemberian bonus atau penghargaan (tidak harus selalu berupa materi) kepada tim terbaik. Model Coopertive Learning teknik STAD menitikberatkan pada kerjasama dalam satu kelompok untuk memecahkan masalah secara bersama-sama.

\section{METODE PENELITIAN}

\section{A. Setting Penelitian}

1. Tempat Penelitian

Dalam penelitian ini penulis mengambil lokasi di kelas I SDN 024 Rambah Hilir yang beralamat 024 Rambah Hilir 
2. Waktu Penelitian

Waktu yang dibutuhkan dalam pelaksanaan kegiatan penelitian ini adalah 3 bulan, yaitu dari bulan Juli 2018 sampai September 2018 dengan perhitungan waktu kurang lebih 12 minggu. Secara lebih rinci dapat dilihat pada bagian lampiran 3 tentang Jurnal Kegiatan Penelitian.

\section{B. Metode dan Rancangan Penelitian}

PTK merupakan kegiatan perbaikan pembelajaran yang terdiri dari beberapa rangkaian kegiatan yang saling berkaitan dan berdaur atau siklus dengan empat langkah utama yaitu perencanaan tindakan, pelaksanaan tindakan, observasi dan refleksi. Tahapan PTK di sini sebenarnya merupakan reflektif guru pada permasalahan yang dihadapi dalam kelasnya. Dari sinilah penelitian tindakan kelas akan dilakukan. Penjelasan secara rinci mengenai

daur siklus PTK sebagaimana gambar 3.1 di bawah ini

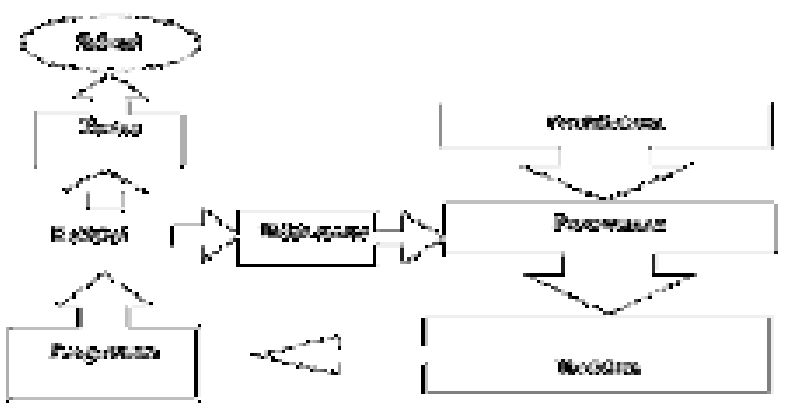

Gambar 1. Daur PTK (dimodifikasi dari Arikunto, 2006 : 46)

Prosedur sebagaimana dijelaskan pada daur PTK di atas, selanjutkan ditindaklanjuti dengan kegiatan-kegiatan :

1. Perencanaan

Perencanaan selalu mengacu kepada tindakan apa yang dilakukan, dengan mempertimbangkan keadaan dan suasana obyektif dan subyektif. Dalam perencanaan tersebut, perlu dipertimbangkan tindakan khusus apa yang dilakukan, apa tujuannya. Mengenai apa, siapa melakukan, bagaimana melakukan, dan apa hasil yang diharapkan. Setelah pertimbangan itu dilakukan, maka selanjutnya disusun gagasan-gagasan dalam bentuk rencana yang dirinci. Kemudian gagasan-gagasan itu diperhalus, hal-hal yang tidak penting dihilangkan, pusatkan perhatian pada hal yang paling penting dan bermanfaat bagi upaya perbaikan yang dipikirkan. Sebainya perencanaan tersebut didiskusikan dengan Guru yang lain untuk memperoleh masukan.

2. Pelaksanaan Tindakan

Jika perencanan yang telah dirumuskan sebelumnya merupakan perencanaan yang cukup matang, maka proses tindakan sematamata merupakan pelaksanaan perencanaan itu. Namun, kenyataan dalam praktik tidak sesederhana yang dipikirkan. Oleh sebab itu, pelaksanaan tindakan boleh jadi berubah atau dimodifikasi sesuai dengan keperluan di lapangan. Tetapi jangan sampai modifikasi yang dilakukan terlalu jauh menyimpang. Jika perencanaan yang telah dirumuskan tidak dilaksanakan, maka Guru hendaknya merumuskan perencanaan kembali sesuai dengan fakta baru yang diperoleh.

\section{Pengamatan}

Hal yang tidak bisa dilupakan, bahwa sambil melakukan tindakan hendaknya juga dilakukan pemantauan secara cermat tentang apa yang terjadi. Dalam pemantauan itu, lakukan pencatatan-pencatatan sesuai dengan form yang telah disiapkan. Catat pula gagasangagasan dan kesan-kesan yang muncul, dan segala sesuatu yang benar-benar terjadi dalam proses pembelajaran. Secara teknis operasional, kegiatan pemantauan dapat dilakukan oleh Guru lain. Di sinilah letak kerja kolaborasi antar profesi. Namun, jika petugas pemantau itu bukan rekanan peneliti, sebaiknya diadakan sosialisasi materi pemantauan untuk menjaga agar data yang dikumpulkan tidak terpengaruh minat pribadinya. Untuk memperoleh data yang lebih obyektif,

\section{Refleksi}

Refleksi adalah suatu upaya untuk mengkaji apa yang telah terjadi, yang telah dihasilkan, atau apa yang belum dihasilkan, atau apa yang belum tuntas dari langkah atau upaya yang telah dilakukan. Dengan perkataan lain, refleksi merupakan pengkajian terhadap keberhasilan atau kegagalan pencapaian tujuan 


\section{Subjek Penelitian}

Subjek penelitian dalam penelitian ini adalah siswa kelas I SDN 024 Rambah Hilir Tahun Pelajaran 2018 / 2019 dengan jumlah siswa sebanyak 16 siswa terdiri dari siswa laki-laki dan perempuan

\section{Indikator dan Kriteria Keberhasilan}

Indikator yang digunakan untuk mengukur peningkatan aktivitas siswa menggunakan 12 indikator. Kriteria keberhasilan yang digunakan untuk mengukur tingkat keberhasilan proses pembelajaran melalui upaya perbaikan pembelajaran sebagai berikut :

1. Proses perbaikan pembelajaran dinyatakan berhasil apabila siswa dapat menguasai minimal $70 \%$ dari materi pembelajaran atau mendapat nilai 76 .

2. Proses perbaikan pembelajaran dinyatakan berhasil apabila $85 \%$ dari jumlah siswa tuntas belajar.

3. Proses perbaikan pembelajaran dinyatakan berhasil apabila $85 \%$ dari jumlah siswa mengalami peningkatan minat belajarnya selama proses pembelajaran berlangsung.

\section{HASIL TINDAKAN DAN PEMBAHASAN Hasil Penelitian}

Analisis data hasil penelitian yang telah dilaksanakan dalam 2 siklus dengan 2 pertemuan pada masing-masing siklusnya secara jelas dapat dijelaskan pada penjelasan di bawah ini.

\section{Siklus Pertama}

Pada siklus pertama, setidaknya upaya perbaikan yang dilakukan melalui kegiatan ceramah dan penerapan model pembelajaran STAD dengan membagi siswa menjadi beberapa kelompok dengan anggota yang heterogen yang terdiri dari 5-6 orang, sehingga terbentuk 3 kelompok dan dilanjutkan dengan kegiatan tanya jawab dan diskusi dapat membuktikan hipotesis peneliti.

a. Aktivitas Belajar

Peningkatan aktivitas belajar cukup signifikan pada setiap siklusnya, dimana pada studi awal hanya $12,50 \%$ atau 2 siswa, meningkat menjadi $62,50 \%$ atau 10 siswa pada siklus pertama. Dalam bentuk grafik sebagaimana gambar di bawah ini :

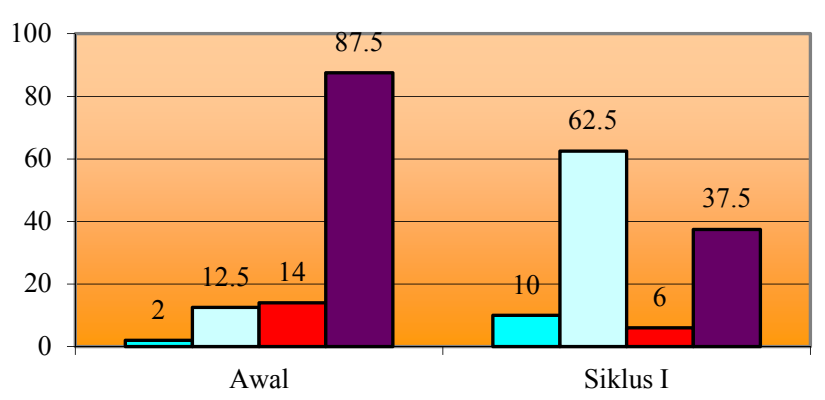

Gambar 2. Diagram Batang Peningkatan Aktivitas dan Ketuntasan Belajar Siswa pada Studi Awal dan Siklus I

Melihat hasil di atas maka peneliti bersama-sama dengan observer sepakat untuk melaksanakan perbaikan pembelajaran pada siklus II dengan harapan pada siklus II aktivitas belajar siswa dapat mencapai perolehan di atas $85 \%$ sesuai dengan kriteria keberhasilan yang telah ditetapkan.

b. Hasil Belajar

Sepertinya halnya peningkatan aktivitas belajar, hasil belajarpun meningkat cukup baik, yaitu dari nilai rata-rata hasil belajar sebesar 65,50 meningkat menjadi 74,56 pada siklus I, sedangkan tingkat ketuntasan belajar mencapai angka 10 siswa atau $62,50 \%$. Untuk memperjelas peningkatan hasil belajar siswa, dapat dilihat pada grafik di bawah ini :

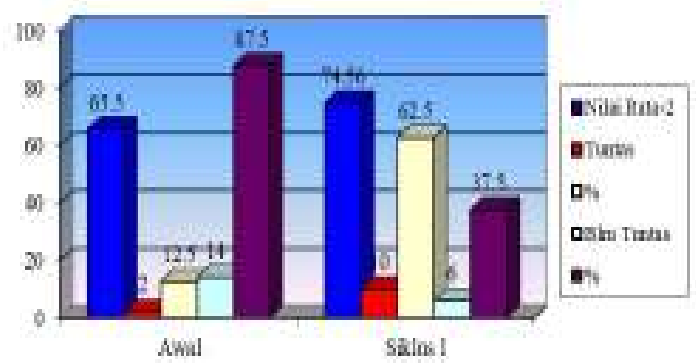

Gambar 3. Diagram Garis Peningkatan Hasil dan Ketuntasan Belajar Siswa pada Studi Awal dan Siklus I

Melihat hasil di atas maka peneliti bersama-sama dengan observer sepakat untuk melaksanakan perbaikan pembelajaran pada siklus II, karena nilai rata-rata hasil belajar baru mencapai angka 74,56 yang berarti masih berada di bawah KKM sebesar 76 sesuai dengan kriteria keberhasilan yang telah ditetapkan dan tingkat ketuntasan belajar baru $62,50 \%$. Hal ini menunjukkan ketuntasan 
belajar belum mencapai $85 \%$ dari jumlah seluruh siswa sesuai dengan kriteria keberhasilan yang telah ditentukan

Setelah menganalisis hasil belajar, hasil angket, hasil observasi, dan wawancara siswa, peneliti melakukan refleksi yang hasilnya sebagai berikut:

a. Perlunya peningkatan hasil belajar yang lebih baik.

b. Pembelajaran dilakukan secara logis.

c. Mengatur waktu yang efektif dan efisien

d. Semangat siswa yang baik dalam pembelajaran sebelumnya, harus dijaga dan dipupuk terus menerus.

e. Hasil refleksi ini akan akan dijadikan bahan perbaikan untuk pertemuan selanjutnya

f. Hal ini dapat dibuktikan dengan masih rendahnya tingkat kreatifitas siswa dalam mengajukan pertanyaan-pertanyaan sekitar materi pembelajaran

g. Harus menunjukan kegairahan dalam pembelajaran, guru menyadari masih kurang bergairah dalam pembelajaran sehingga belajar menjadi lebih bersemangat kepada siswa

Setelah peneliti dan observer mendiskusikan tentang hasil observasi yang dikaitkan dengan hasil tes formatif maka, kelemahan pada siklus pertama akan ditanggulangi pada siklus kedua dengan :

a. Mengefektifkan fungsi kerja kelompok secara lebih optimal dengan menerapkan rolling anggota kelompok, dimana siswa tuntas akan digabung dengan siswa belum tuntas dengan persentase yang berimbang, dengan harapan siswa tuntas dapat membimbing siswa yang belum tuntas belajarnya.

b. Lebih mengoptimalkan penggunaan lembar kerja siswa dan kegiatan tanya jawab serta diskusi antar dan sesama anggota kelompok dengan menambah variasi soal pada lembar kerja siswa.

c. Mengefektifikan kegiatan tanya jawab pada akhir kegiatan pembelajaran

d. Bekerja sama dengan observer untuk melakukan pencatatan skor baik individu maupun kelompok untuk memberikan penghargaan kepada siswa atau kelompok yang meraih prestasi tertinggi pada akhir kegiatan pembelajaran

Siklus Kedua

Selanjutnya dengan melakukan diskusi kelas dengan fokus perhatian pada siswa belum tuntas, kepadanya diberikan kesempatan untuk mengemukakan masalah yang dihadapi dan ditemukan untuk dibahas dalam pelaksanaan diskusi kelas.

a. Aktivitas Belajar

Peningkatan aktivitas belajar cukup signifikan pada setiap siklusnya, dimana pada siklus pertama hanya 10 siswa atau $62,50 \%$, meningkat menjadi $100 \%$ atau 16 siswa pada siklus kedua yang terlibat aktif dalam pelaksanaan pembelajaran. Dalam bentuk grafik sebagaimana gambar di bawah ini :

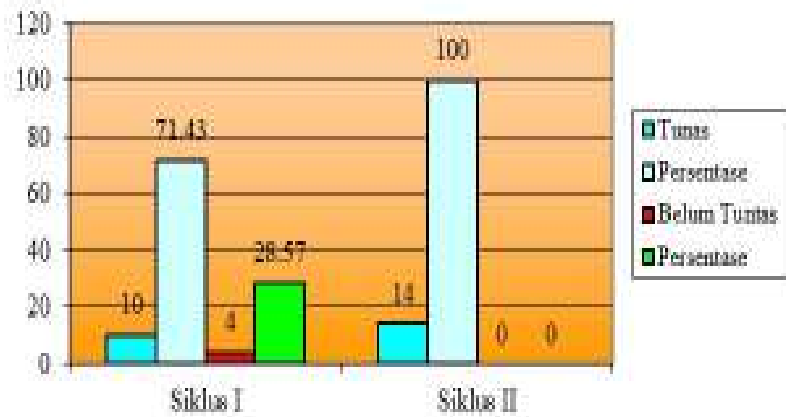

\section{Gambar 4. Diagram Batang Peningkatan Aktivitas dan Ketuntasan Belajar Siswa Siklus I dan Siklus II}

Melihat hasil di atas maka peneliti bersama-sama dengan observer menyimpulkan bahwa aktivitas belajar mencapai angka 100\%. Hal ini menunjukkan bahwa aktivitas belajar telah mencapai kriteria keberhasilan sebesar $85 \%$ dari jumlah seluruh siswa, sehingga proses perbaikan dinyatakan berhasil dan tuntas pada siklus kedua.

\section{b. Hasil Belajar}

Sepertinya halnya peningkatan aktivitas belajar, hasil belajarpun meningkat cukup baik, yaitu dari nilai rata-rata hasil belajar sebesar 74,56 pada siklus pertama, menjadi 83,00 pada siklus kedua, sedangkan tingkat ketuntasan belajar mencapai angka 15 siswa atau 93,75\%. Untuk memperjelas peningkatan hasil belajar siswa, dapat dilihat pada grafik di bawah ini : 


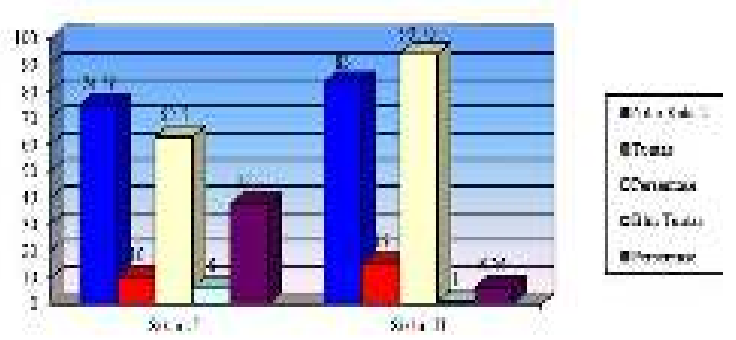

Gambar

5. Diagram Peningkatan Hasil dan Ketuntasan Belajar Siswa pada Siklus I dan Siklus II

Melihat hasil di atas maka peneliti bersama-sama dengan observer menyimpulkan bahwa rata-rata hasil belajar menunjukkan hasil 83,00, yang berarti sudah melebihi KKM minimal 76, dengan jumlah siswa yang telah tuntas belajarnya sebanyak 16 siswa atau 93,75\%. Hal ini menunjukkan bahwa ketuntasan belajar juga telah mencapai kriteria keberhasilan sebesar $85 \%$ sehingga proses perbaikan pembelajaran dinyatakan berhasil dan tuntas pada pelaksanaan siklus II

Pembelajaran PKn pada siklus kedua ini sudah berhasil, karena sudah memenuhi kriteria keberhasilan yang ditentukan. Pada siklus II ini kegiatan pembelajaran sudah cukup lancar. Siswa sudah menunjukan keantusiasan tinggi untuk belajar PKn dan lembar kerja siswa dikerjakan dengan baik dan hasilnya pun baik juga. Walaupun demikian masih ada saja gangguan, tetapi sedikit dan tidak berpengaruh terhadap proses pembelajaran. Hampir semua siswa sudah berkonsentrasi untuk memecahkan soal penalaran PKn dalam lembar kerja siswa. Untuk mengetahui tingkat kemampuan siswa yang telah dicapai dalam pembelajaran siklus II, maka dilakukan analisis terhadap hasil tes siklus II yang mengacu kepada materi pelajaran yang diserap dan ketuntasan belajar yang dihitung persentase rata-rata dan daya serapnya dan ketuntasan dalam belajar. Selanjutnya peneiti dengan supervisor dan observer mendiskusikan tentang hasil observasi dan wawancara yang dikaitkan dengan hasil tes formatif, maka pembelajaran PKn dianggap sudah tuntas karena hanya dua orang yang belum tuntas belajarnya sehingga pembelajaran $\mathrm{PKn}$ dapat dilanjutkan pada materi berikutnya karena sudah mencapai kriteria keberhasilan proses perbaikan pembelajara seduai dengan yang telah ditetapkan.
Antar Siklus

Penggunaan model cooperative learning tipe STAD akan sangat membantu dalam membangkitkan aktivitas belajar siswa, ini terbukti dari hasil belajar yang diberikan pada setiap siklusnya mengalami peningkatan di mana pada studi awal sebesar 66,43 , pada siklus I nilai rata-rata yang diperoleh siswa adalah 71,86 dan pada siklus II rata-rata nilai yang diperoleh siswa adalah 83,29. Rekapitulasi nilai hasil tes formatif siswa dari kondisi awal, siklus I sampai dengan siklus II dapat dilihat dari tabel di bawah ini.

Tabel 1. Rekapitulasi Nilai Hasil Tes Formatif Temuan Awal, Siklus I dan Siklus II

\begin{tabular}{|c|c|c|c|c|c|c|c|}
\hline \multirow{2}{*}{ No } & \multirow{2}{*}{ Siklus } & \multirow{2}{*}{ Nilai } & \multicolumn{5}{|c|}{ Ketuntasan } \\
\cline { 4 - 7 } & & Tuntas & $\%$ & $\begin{array}{c}\text { Belum } \\
\text { Tuntas }\end{array}$ & $\%$ & \\
\hline 1 & Awal & 65,50 & 2 & 12,50 & 14 & 87,50 & \\
\hline 2 & $\begin{array}{c}\text { Siklus } \\
\text { I }\end{array}$ & 74,56 & 10 & 62,50 & 6 & 37,50 & \\
\hline 3 & $\begin{array}{c}\text { Siklus } \\
\text { II }\end{array}$ & 83,00 & 15 & 93,75 & 1 & 6,25 & \\
\hline
\end{tabular}

Dari tabel di atas dapat dijelaskan peningkatan nilai hasil dan ketuntasan belajar siswa pada siklus I dan II secara terperinci sebagai berikut :

\section{Siswa Tuntas Belajar}

a. Pada temuan awal siswa yang tuntas sebanyak 2 siswa atau $12,50 \%$ dari 16 siswa.

b. Pada siklus I siswa yang tuntas sebanyak 10 siswa atau $62,50 \%$ dari 16 siswa

c. Pada siklus II siswa yang tuntas sebanyak 15 siswa atau $93,75 \%$ dari 16 siswa

\section{Siswa Belum Tuntas Belajar}

a. Pada temuan awal siswa yang belum tuntas sebanyak 14 siswa atau $87,50 \%$ dari 16 siswa.

b. Pada siklus I siswa yang belum tuntas sebanyak 6 siswa atau $37,50 \%$ dari 16 siswa

c. Pada siklus II siswa yang belum tuntas sebanyak 1 siswa atau $6,25 \%$ dari 16 siswa tuntas belajarnya.

Untuk memperjelas kenaikan ketuntasan belajar siswa dan penurunan ketuntasan belajar siswa dapat dilihat pada diagram batang di bawah ini : 


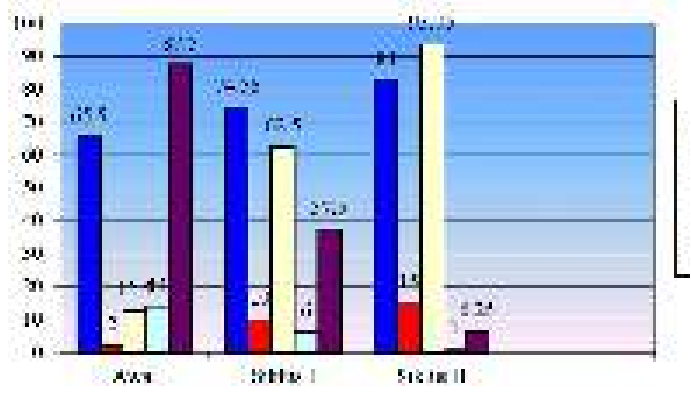

Gambar 6.

Grafik

Peningkatan dan Penurunan Ketuntasan Belajar Siswa Siklus I dan II

Penjelasan mengenai peningkatan nilai rata-rata hasil belajar pada pembelajaran Pendidikan Kewarganegaraan materi Menjelaskan perbedaan jenis kelamin, agama, dan suku bangsa dengan menggunakan penerapan model cooperative learning tipe STAD menunjukkan peningkatan yang cukup signifikan di mana pada kondisi awal sebesar 65,50 meningkat menjadi 74,56 pada siklus I dan pada akhir siklus II meningkat menjadi 83,00 . Peningkatan nilai rata-rata hasil belajar siswa dalam bentuk grafik sebagaimana gambar di bawah ini :

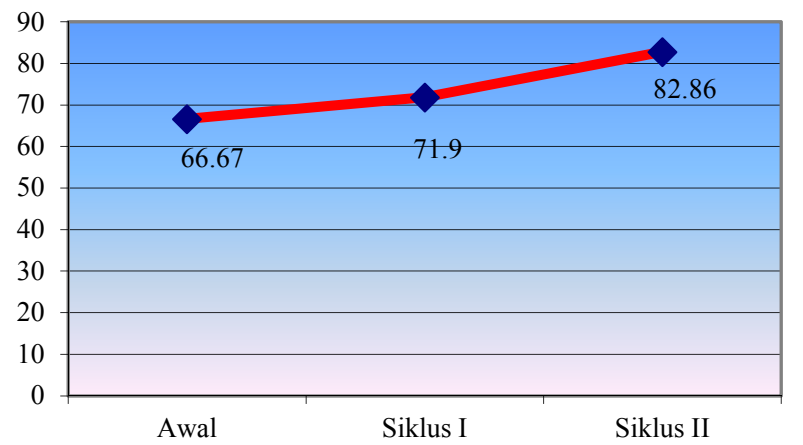

Gambar 7. Grafik Peningkatan Nilai Rata-rata Belajar Siswa Pada Siklus I dan II

Keberhasilan proses perbaikan pembelajaran tidak hanya dilihat dari peningkatan hasil belajar atau nilai tes formatif saja. Aktivitas belajar siswa selama proses pembelajaran juga merupakan indikator keberhasilan dalam proses pembelajaran. Hasil observasi pada pelaksanaan kegiatan perbaikan pembelajaran menunjukkan hasil yang positifi, dan dibuktikan dengan adanya peningkatan aktivitas siswa pada setiap siklusnya. Secara rinci penjelasan mengenai peningkatan aktivitas siswa dalam proses perbaikan pembelajaran sebagaimana tabel di bawah ini :
Tabel 2. Rekapitulasi

Peningkatan Aktivitas Siswa pada Siklus I dan Siklus II

\begin{tabular}{|c|c|c|c|c|c|c|}
\hline \multirow{2}{*}{ No } & \multirow{2}{*}{ Siklus } & \multicolumn{2}{|c|}{ Tuntas } & \multicolumn{2}{|c|}{ Belum Tuntas } & \multirow{2}{*}{ Ket } \\
\cline { 3 - 6 } & & Jumlah & $\%$ & Jumlah & $\%$ & \\
\hline 1 & Awal & 3 & 18,75 & 13 & 81,25 & \\
\hline 2 & Siklus I & 10 & 62,50 & 6 & 37,50 & \\
\hline 3 & $\begin{array}{c}\text { Siklus } \\
\text { II }\end{array}$ & 16 & 100,00 & 0 & 0,00 & \\
\hline
\end{tabular}

Dari tabel di atas dapat dijelaskan tentang siswa yang tuntas dan belum tuntas dilihat dari aktivitas belajarnya, yaitu :

a. Siswa tuntas dilihat dari aktivitas belajar

1. Pada temuan awal, siswa tuntas dilihat dari aktivitas belajar sebanyak 3 siswa atau $18,75 \%$ dari 16 siswa.

2. Pada siklus I, siswa tuntas dilihat dari aktivitas belajar sebanyak 10 siswa atau $62,50 \%$ dari 16 siswa.

3. Pada siklus II, siswa tuntas dilihat dari aktivitas belajar sebanyak 16 siswa atau $100 \%$ dari 16 siswa.

b. Siswa yang belum tuntas dilihat dari aktivitas belajar

1. Pada temuan awal, siswa belum tuntas dilihat dari aktivitas belajar sebanyak 13 siswa atau $81,25 \%$ dari 16 siswa.

2. Pada siklus I, siswa belum tuntas dilihat dari aktivitas belajar sebanyak 6 siswa atau 37,50\% dari 16 siswa.

3. Pada siklus II, tidak ada siswa yang tidak tuntas dilihat dari aktivitas belajar dari 16 siswa.

Secara jelas peningkatan aktivitas siswa selama proses perbaikan pembelajaran sebagaimana dijelaskan pada gambar di bawah ini :

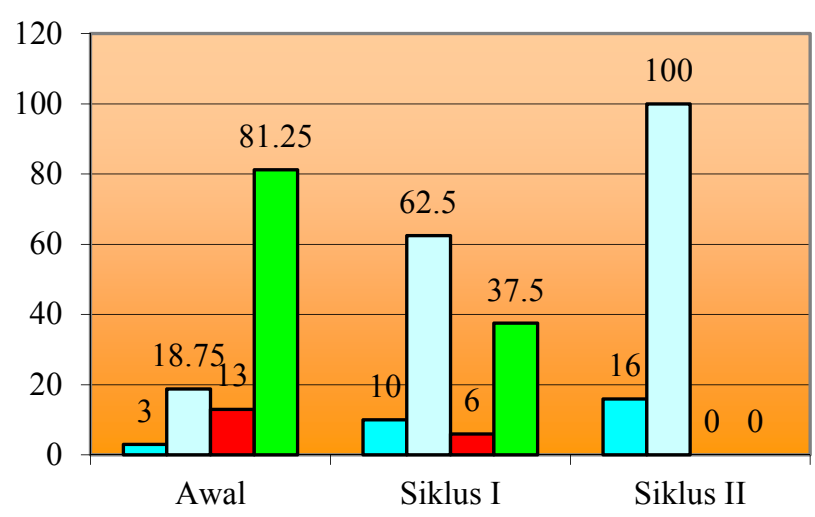

Gambar 8. Grafik Ketuntasan Siswa Berdasarkan Tingkat Aktivitas Siswa Pada Siklus I dan II 
Dari hasil observasi mengenai aktivitas siswa tersebut berdasarkan kriteria keberhasilan perbaikan pembelajaran dapat disimpulkan bahwa proses perbaikan pembelajaran dinyatakan berhasil karena peningkatan aktivitas siswa mencapai angka $100 \%$ dari $85 \%$ batasan minimal yang telah ditentukan pada kriteria keberhasilan proses perbaikan pembelajaran. Atas dasar pertimbangan sebagaimana diurakan di atas, maka peneliti dan observer sepakat memutuskan bahwa kegiatan perbaikan pembelajaran diakhiri pada siklus II.

\section{Pembahasan}

Melalui pembelajaran kooperatif tipe STAD ini terlihat hubungan siswa dengan guru sangat signifikan, karena guru dianggap sosok yang menakutkan tetapi sebagai fasilitator dan mitra untuk berbagi pengalaman sesuai dengan konsep creative learning yaitu melalui discovery dan invention serta creativing and diversity sangat menonjol dalam pembelajaran ini. Dengan model pembelajaran kooperatif tipe STAD guru hanya mengarahkan strategi yang efektif dan efisien yaitu belajar bagaimana cara belajar (learning now to learn). Dalam hal ini guru memberi arah/petunjuk untuk membantu siswa jika menemukan kesulitan dalam mempelajari dan menyelesaikan masalah.

Dalam model pembelajaran kooperatif tipe STAD, melalui diskusi kelompok guru dapat mengamati karakteristik atau gaya belajar masing-masing siswa. Ada kelompok siswa yang suka membaca daripada dibacakan kasusnya oleh orang lain. Siswa yang lebih suka membaca kasus dalam hal ini tergolong kepada siswa yang memiliki potensi atau modalitas visual. Sedangkan siswa yang lebih suka berdialog, saling mengajukan argumentasi dengan cara mendengarkan siswa yang lain sewaktu menyampaikan pendapatnya tergolong kepada siswa yang memiliki potensi atau modalitas auditorial. Dan siswa yang dengan lugas, lincah dan fleksibel, selain melihat, mendengar uraian dari siswa yang lain, dia juga mengakomodir semua permasalahan, maupun membuktikan teori ke dalam praktik, maupun memecahkan masalah secara rasional, tergolong kepada kelompok belajar yang memiliki potensi atau modalitas kinestik.

Dalam proses belajar mengajar dengan model pembelajaran kooperatif tipe Student
Teams Achievement Divisions (STAD), guru lebih berperan sebagai fasilitator dan pengarah dan pemberi materi kepada siswa. Siswa diberikan kesempatan untuk berdiskusi dan menyelesaikan soal praktek dengan teman satu timnya, guru hanya bertugas sebagai pengarah. Dengan melalui model pembelajaran kooperatif tipe Student Teams Achievement Divisions (STAD), dimaksudkan untuk meningkatkan hasil belajar siswa.

Hal ini dapat dilihat dari data hasil penelitian yang dilaksanakan pada siklus I, siswa yang memperoleh nilai minimal 76 atau tuntas adalah adalah 10 orang siswa $(62,50 \%)$ dan nilai rata-rata hasil belajar siswa mencapai angka 74,56. Di samping itu hasil pengamatan aktivitas belajar siswa pada siklus II dari proses pembelajaran menunjukkan 16 siswa atau $100 \%$ dinyatakan tuntas

Dari data yang diperoleh tersebut dapat digambarkan bahwa masih perlu adanya perbaikan terutama pada hasil belajar baik secara individual maupun secara klasikal. Kelemahan-kelemahan yang terjadi pada siklus I adalah (1) Guru belum mampu menciptakan interaksi yang aktif anatara siswa dengan siswa, siswa dengan guru (2) penguasaan alat bantu media yang belum cerar optimal di kuasai (3) peranan guru dalam menyelesaikan masalah belum maksimal (4) buku penunjang yang digunakan yang masih kurang (5) hasil belajar siswa belum mencapai target yang diharapkan. Berdasarkan kelemahan-kelemahan yang terjadi pada siklus I, maka guru melakukan perbaikan strategi pembelajaran pad siklus II. Adapun perubahan yang terjadi pada siklus II antara lain: (1) Pendekatan guru seperti apersepsi, motivasi dan menciptakan interkasi yang aktif dengan siswa sudah sangat baik, pengelolaan kelas yang sudah sesuai, sehingga siswa begitu semangat untuk belajar aktif dalam mengikuti pelajaran, siswa menjadi tidak malu bertanya dan siswa tidak merasakan bosan atau jenuh dalam menerima materi (2) partisipasi dan respon siswa menerima penjelasan guru, mengajukan pertanyaan sesuai dengan materi yang dibahas sangat memenuhi harapan yang di harapkan (3) Daya serap siswa dalam penguasaan konsep atau materi sudah memenuhi kriteria belajar dan ketuntasan 
penelitian dan hasil belajar siswa sudah mencapai target yang diharapkan.

Dari hasil perbaikan strategi pembelajaran tersebut, maka pada siklus II telah terjadi perubahan, baik dari segi hasil belajar maupun proses pembelajaran. Perubahan-perubahan tersebut antara lain jumlah siswa yang tuntas belajar atau memperoleh nilai minimal 76 pada siklus I adalah 10 orang siswa $(62,50 \%)$, pada siklus II meningkat menjadi 15 orang siswa $(93,75 \%)$ dengan perolehan nilai rata-rata pada siklus I sebesar 74,56 meningkat menjadi 83,00 pada siklus II. Aktivitas belajar siswa pada siklus I sebesar $62,50 \%$ atau 10 siswa dinyatakan tuntas dan pada siklus II meningkat menjadi 16 siswa atau $100 \%$ siswa dinyatakan tuntas dinilai dari peningkatan aktivitas belajarnya menggunakan 12 indikator.

Berdasarkan deskripsi data tersebut di atas, jelas bahwa aktivitas dan hasil belajar siswa mengalami peningkatan baik pada siklus I. Pada siklus II inilah peningkatan aktivitas dan hasil belajar siswa telah mencapi ukuran tingkat keberhasilan penelitian atau indikator kinerja yang telah ditentukan. Berdasarkan data-data hasil pelaksanaan perbaikan pembelajaran sebagaimana diuraikan di atas berupa data hasil tes formatif siklus I, tes formatif siklus II dan data hasil observasi siklus I dan II maka dapat disimpulkan bahwa penerapan model cooperative learning tipe STAD dapat meningkatkan hasil belajar dan aktivitas siswa pada pembelajaran Pendidikan Kewarganegaraan materi menjelaskan Menjelaskan perbedaan jenis kelamin, agama, dan suku bangsa di Kelas I SDN 024 Rambah Hilir Tahun Pelajaran 2018 / 2019

\section{KESIMPULAN}

Berdasarkan hasil analisis data dan temuan, akhirnya dapat diambil suatu kesimpulan sebagai berikut :

1. Model pembelajaran Cooperative Learning Tipe STAD dapat dilaksanakan dalam pembelajaran, terbukti efektif dalam menanamkan sikap dan perilaku sosial siswa. Dalam pelaksanaan pembelajaran, siswa belajar secara berkelompok yang tiap kelompoknya terdiri dari 5 sampai 6 orang dengan bantuan alat peraga dan LKS. Kelompok dibentuk secara heterogen karena pembelajaran yang dilaksanakan menerapkan
Cooperative Learning tipe STAD. Langkahlangkah pembelajaran Cooperative Learning tipe STAD adalah sebagai berikut, guru menyampaikan apersepsi berupa pertanyaan untuk menggali pengetahuan awal siswa, kemudian mengenalkan materi yang akan dibahas serta menyampaikan tujuan yang ingin dicapai sesuai dengan rencana pembelajaran, eksplorasi dilaksanakan secara berkelompok untuk menyelesaikan LKS yang berisi permasalahan yang harus diselesaikan dalam kelompok. Guru membimbing dan mengarahkan siswa baik secara kelompok maupun individu sambil menilai sikap dan perilaku sosial siswa dalam kelompoknya. Setelah menyelesaikan LKS, secara bergiliran tiap kelompok mempresentasikan hasil kerja kelompoknya di depan kelas, siswa yang lain menanggapinya. Guru menyamakan persepsi atas materi dari tiap kelompok dan memberikan penghargaan terhadap unjuk kerja siswa. Di akhir pembelajaran siswa diberikan tes evaluasi secara individual untuk mengetahui pemahaman siswa terhadap materi pembelajaran.

2. Aktivitas belajar siswa dalam kegiatan diskusi pada materi pembelajaran PKn materi Menjelaskan perbedaan jenis kelamin, agama, dan suku bangsa dengan menerapkan model Cooperative Learning STAD menjadi meningkat dilihat dari siklus I siswa belum berani mengemukakan pendapat, belum berani bertanya, belum berani memberikan tanggapan terhadap pendapat teman, dan belum mampu berkomunikasi antar anggota kelompok, bahkan pada siklus II nampak bahwa siswa berani mengemukakan pendapat, bertanya memberikan tanggapan terhadap pendapat teman, dan mampu berkomunikasi antar anggota kelompok.

3. Hasil belajar siswa terhadap pembelajaran PKn materi Menjelaskan perbedaan jenis kelamin, agama, dan suku bangsa setelah menerapkan model Cooperative Learning STAD menunjukan adanya peningkatan hal ini terbukti dari hasil tes formatif dan observasi secara individu dari tiap siklus. Adapun hasil rata-rata tes formatif secara individu adalah sebagai berikut : kondisi awal sebesar 65,50, siklus I adalah 74,56, siklus II adalah 83,00 dengan ketuntasan belajar dari 2 
siswa atau $12,50 \%$ menjadi $62,50 \%$, atau 10 siswa dan 93,75\% atau 15 siswa pada siklus terakhir serta penilaian hasil observasi aktivitas belajar yang juga meningkat di mana pada kondisi awal sebesar 18,75\% atau 3 siswa, siklus I sebesar $62,50 \%$ atau 10 siswa, meningkat menjadi $100 \%$ atau 16 siswa.

\section{DAFTAR PUSTAKA.}

A.M, Sardiman. 2011. Interaksi dan Motivasi Belajar Mengajar. Jakarta: Rajawali Pers.

Agustien, Helena H. 2004. "Rasional Perubahan Kurikulum". Makalah pada Diskusi Penilaian Buku di Pusat Perbukuan, Departemen Pendidikan Nasional

Ali Imran. 1996. Belajar dan Pembelajaran. Jakarta: PT Dunia Pustaka Jaya

Ali, Muhammad. 2004. Kamus Lengkap Bahasa Indonesia Modren. Jakarta:Pustaka Amani

Arikunto, Suharsimi. 2006. Dasar-Dasar Evaluasi Pendidikan. Jakarta: PT. Bumi Aksara.

Arikunto, Suharsimi. 2010. Prosedur Penelitian Suatu Pendekatan Praktik. Jakarta : Rineka Cipta

Atkinson, Rita L., Atkinson, Richard C., \& Hilgard, Ernest R. 1997. Pengantar Psikologi Ed. 8, Jilid 2. Jakarta: Penerbit Erlangga

BSNP. 2006a. Permendiknas No.22 Tahun 2006 tentang Standar Isi untuk Satuan Pendidikan Dasar dan Menengah. Jakarta: Depdiknas

Cholisin. 2000. Materi Pokok Ilmu Kewarganegaraan-Pendidikan

Kewarganegaraan. UNY. Yogyakarta.

Clark. 1981. Psikologi Pendidikan. Jakarta : Gramedia.

Daryono. 2008. Evaluasi Pendidikan. Jakarta: Rineka Cipta

Didi Sutardi, dkk. 2007 Pembaharuan Dalam PBM di Sekolah Dasar. Bandung: UPI PRESS.

Hadari Nawawi. 2006. Evaluasi dan Manajemen Kinerja di Lingkungan Perusahaan dan Industri. Yogyakarta: Gadjah Mada University Press

Hasibuan. 2010. Manajemen Sumber Daya Manusia. Jakarta: Bumi Aksara
Joyce, B., Weil, M., and Shower, B. 1992 Models of Teaching. Massachusetts: Allyn and Bacon.

Kamus Besar Bahasa Indonesia Edisi Kedua. 1989. Balai Pustaka. Jakarta

Karli, Hilda dan Margaretha. 2002. Implementasi Kurikulum Berbasis Kompetensi 2. Bandung : Bina Media Informasi

Kasihani Kasbolah. 1999. Penelitian Tindakan Kelas PTK. Jakarta : Departemen Pendidikan dan Kebudayaan

Miles, B.B., dan A.M. Huberman, 1992, Analisa Data Kualitatif, UI Press Jakarta

Moleong, Lexy J. 2007. Metodologi Penelitian Kualitatif. Bandung: Remaja Rosdakarya

Nasution S. 2003. Metode Research: Penelitian Ilmiah. Edisi 1. Jakarta: Bumi Aksara.

Nur, M dan Kardi, S. 2000. Pengajaran Langsung. Pusdat Sains dan Matematika Sekolah Program Pasca Sarjana. UNESA

Nurulwati. 2000. Model-model Pembelajaran. Surabaya: Universitas Negeri Surabaya

Oemar Hamalik. 2007. Kurikulum dan Pembelajaran. Jakarta: PT. Bumi Aksara.

Purwanto,

Ngalim. 1990. Psikologi Pendidikan.

Jakarta:Remaja Rosda Karya

Rahman, Masykur Arif. 2011. KesalahanKesalahan Fatal Paling Sering Dilakukan Guru Dalam Kegiatan Belajar Mengajar, Jogjakarta: Diva Press.

Sagala, Syaiful. 2011. Konsep dan Makna Pembelajaran. Bandung : Alfabeta.

Samsuri, 2011. Pendidikan Karakter Warga Negara, Kritik Pembangunan Karakter Bangsa. Yogyakarta: Diandra Pustaka Indonesia

Sanjaya, W. 2006. Strategi Pembelajaran. Jakarta: Kencana Prenada Media Group.

Slameto. 2010. Belajar dan Faktor-Faktor Yang mempengaruhinya. Jakarta : Rineka Cipta

Slavin, Robert E. 2005. Cooperative Learning: theory, research and practice N. Yusron. Terjemahan. London: Allymand Bacon. Buku asli diterbitkan tahun 2005

Sudjana N. 2000. Dasar-dasar Proses Belajar Mengajar. Bandung: Sinar Baru. 
Sudjana, Nana. 1989. Penilaian Hasil Proses Belajar Mengajar. Bandung: Remaja Rosdakarya.

Sudjana, Nana. 1991. Dasar-Dasar Proses Belajar Mengaja. Bandung: Sinar Baru Algensindo.

Sudjana, Nana. 2004. Landasan Psikologi Pendidikan. Jakarta: Remaja Rosdakarya.

Surya, Moh. 1981. Pengantar Psikologi Pendidikan. Bandung: FIP IKIP Bandung

Suryabrata, Sumardi. 1984. Psikologi Pendidikan. Jakarta: CV. Rajawali.

Tusilawati, Hefi. 2010. Penerapan Metode Problem Solving Untuk Meningkatkan Hasil Belajar Siswa Dalam Pembelajaran IPS di Kelas VI Sekolah Dasar. Skripsi UPI Bandung. Tidak diterbitkan.

Usman, Moh Uzer. 2009. Menjadi Guru Profesional. Bandung: Remaja Rosdakarya 